\title{
The Struggle for Power in Post-Colonial Africa: Politics without Hegemony and the State.
}

\author{
Dr. M. M. Fadakinte \\ Department of Political Science, \\ Faculty of Social Sciences, University of Lagos.
}

\begin{abstract}
Scholars have explained the implications of colonization on Africa, but none has explained the implications to include crisis of hegemony and crisis of state. That is the thrust of this paper, an explanation of how/why post-colonial Africa got enmeshed in violent struggle for power by factions of the dominant class soon after independence. In Africa, colonialism imposed capitalism and inverted the process of evolving a capitalist sate, which made the emerging dominant class, who were of different ethnic and tribal origins, to develop into factions. As a result, the dominant classes were made up of belligerent factions and therefore cannot institute hegemonic process which will be the way they will maintain a dominant culture through the use of social institutions to formalize power. Consequently, in post-colonial Africa, politics is without hegemony (leadership, domination and control) and a state (institution for order). And whenever people struggle for power without hegemony and the state, what emerges is chaos. Hence, post-colonial African countries boil each time there is competition for power. Thus, there is need to redefine state-society relations in post-colonial Africa, based on a new paradigm of state formation that will reflect their colonial experience.
\end{abstract}

Keywords; Hegemony; Colonization; the State; dominant class; African states.

\section{INTRODUCTION}

Post-colonial Africa has been embroiled in series of crises soon after independence and that is because social formations in Africa have been confronted with a rash of struggles in terms of leadership succession i.e. the contest for political power. Thus, power and politics as the contestations for the legitimation of domination have been turned to bitter competitions, resulting in conflicts, violence and bloodshed. Consequently, Africa and her people continue to live with all sorts of crises, such as election violence, ethnic wars, poverty, migration, diseases, and underdevelopment challenges. Therefore, the struggle for power (politics) immediately African countries gained political freedom from their colonial masters, stood for everything but peaceful and violent free competition. Power and politics have, therefore, become two social monsters in Africa, so much so that the continent is today under dangerous siege, wrought on her by these dangerous monsters.

Lasswell and Kaplan,(1950), say that politics is "who gets what, when and how" and that power is a value, an extremely important one, as the explanation for this African problem. With these two definitions, power and politics become values over which people must struggle. However, the problem of the bitter and violent struggle for power, in Africa, is quite beyond the issue of the struggle for resources, it is indeed a problem of the nature and character of the state which reflects the absence of class hegemony, class hegemony as a class requirement for state consolidation. In any case, citizens of countries in Europe and America do periodically struggle for power and their engagement in political competition (politics) rarely end in violence and bloodshed as we regularly witness in Africa. 
Soon after independence, most of the African countries evolved a factionalized dominant class, with all the factions, bitterly and violently struggling for power, a development that has now become their preoccupation. So, ever since independence, the faction that is able to secure power, would privatize it by using nepotism, tribalism, kleptocracy and other spoils of office to hold on to power. In other words, whenever any of the factions of the dominant class is in power, it will do anything to consolidate its position, which they do by ensuring that they control the political space by limiting it to themselves. Therefore, the various factions of the dominant class always take advantage of elections, in particular, elections that stand as legitimate and competitive means to struggle for power, and they do so by using any means. In the process, the factions will engage in electoral competition as if it is warfare. Thus, the ensued belligerency does not allow the dominant class to be cohesive, and by implications they lack the needed peace that will make them to be well organized, so that they are able to rationally plan for development. Hence, there is no meaningful progress in the political, economic and social life of Africans, precisely because political competition is synonymous with warfare.

This paper, therefore, focuses on violent political struggle in Africa, by interrogating the dynamics of state formation processes, class hegemony and the construction of hegemonic process. Thus, crisis of sate formation, as an approach in explaining the problem of violent struggle for power in Africa is very pertinent, in that, the state is the issue when it comes to the struggle for power and that is because the essence of elections and popular competition for power is to grant legitimacy to state power. Thus, whenever the state is in crisis, the crisis will manifest itself in many ways, violent politics, being one. Also, whenever a society does not have a class with the needed hegemony, with which to stabilize the society, the struggle for power in such a society will necessarily be chaotic. This is why state formation processes including the nature and character of the dominant class must be put in proper perspective in order to understand the problem of violent and bitter struggle for power in Africa.

Thus, since independence, African countries have been grappling with violent crises in the process of the struggle for power, the crises that are symptomatic of crisis of state formation.

\section{POWER, POLITICS, HEGEMONY AND THE STATE: SOME CONCEPTUAL NOTES}

From Thomas Hobbes, the concept of power began to assume a central place in the equation of human relations and today the idea of power has become an important concept in the realm of political theory, (Johari, 2012). Therefore, the meaning of politics has now changed from one of being the study of state and government to that of being the study of power. Again, the study of politics, is concerned with the description and analysis of the manner in which power is obtained, exercised and controlled and it is also about the purpose for which power is used, the manner in which it is used and how it is used for policy formulation and other government actions. (Joharis, 2012)

The place and significance of power in any socio-political organization has long been recognised by thinkers making the concept of power to be the key concept in politics and the epicentre of political science. Power to (Ponton and Gill, 1996) is not just one important concept among many, but it is the central concept of political science. Arora, ( 2014) says that politics is all about power or power is the one around which politics revolves because, power is the means through which the state or the government gets things done. Consequently, power and politics go together, they go together because state actions are carried out with the power of the state making the force behind state laws a reflection of power. So, power is seen in the operations of the government. Again the capacity of a state to function efficiently and productively depends on the degree of power the state can muster and that is because power is 
"the ability to get others do what you (state) wishes, assuming this is different from what they would otherwise have done, with the use or threat of sanctions, if necessary". (Ponton and Gill, 1996, pg. 22). For example, the ability of government to make and enforce rules or punish certain behaviours is an important aspect of power. Thus, government cannot maintain peace, guarantee security, promote development or embark on effective policies without power. (Magstadt, 2006). Indeed, power is very central to the study of politics precisely because politics is nothing but the struggle for power, which is why power cannot be separated from politics, more so because all states must possess power which is the most important and essential aspect of any state. (Mahajan, 2008)

However, power may be used in different senses on account of its economic, political, psychological and social ramifications which make the omnipresence of power to be a fact. (Johari, 2012). Thus, power has three broad dimensions, viz political, economic and ideological. Political power belongs to the state which is exercised through the institutions of state. Again, economic power is the power that resides in the place of the ownership and control of the national wealth, such as the ownership and control of land and the means of production and distribution. This is why the capitalists are able to exploit and oppress the working class because by virtue of their control of national wealth, they also have political power in their hands. And ideological power is in the dominant ideas that are generally accepted by the people for which the people have unquestionable faith and for which they strives to put into action. (Johari, 2012)

Power, as an element of the state without which the state cannot function, is now a powerful tool for studying the performance of the state and the conditions of society. (Johari, 2012). The exercise of power invites opposition which makes social conflicts to ensue and which makes Hobbes to argue that man desire power and ever greater power, making the search for power the root cause of competition among individuals. (Johari, 2012)

\section{Politics}

Politics and power are two sides of the same coin. Discussing politics is discussing power because everything about politics revolves round power and discussing power is an exercise about politics because the whole essence of politics is about power

From ancient, through antiquity to the modern and contemporary times, politics keep preoccupying the minds of scholars. Plato and his discussions about education, justice and the stratification of society is all about politics, about the governing and management of the community. And Aristotle says that man is a political animal because, to him, he who is unable to live in society because he is self-sufficient must be either a beast or God.

Politics has various definitions making the concept to have as many definitions as the number of those defining the concept. In a very simple term, (Ponton and Gill, 1996) say that politics is simply the way in which we understand and order our social affairs in terms of the allocation of scarce resources.

Thus, whichever way we define or analyze politics, it has always been about how power is exercised in the society. For example, Easton says that politics is who gets what, when and how, the definition that portrays politics as the exercise of power in the distribution of scarce resources. Damziger, 2001, defines politics as the exercise of power, the resolution of conflicts, and public allocation of things that are valued. 
However, looking at the movement of thoughts about politics, the concept can be discussed under two broad perspectives. Today, politics can be discussed under the traditional and modern views. According to (Mahajan, 2008), the traditional view of politics is about the study of the state or government and state institutions. Under this view, politics is seen as an activity that is concerned with people's survival and material relationship, expressed in various ways by different people. (Ponton and Gill, 1996). The traditional perspective also sees politics as the working of common decisions for groups of people. (Shively, 2012).

The modern view of politics sees politics from power perspective, that is, the power theory of politics. Thus, politics is described as activities of the government (state) and its relationship with the individuals, groups, and the outside world. Also, the modern view defines politics as the struggle for power to make authoritative decisions for the whole society. (Maharajan, 2008).

From all perspectives, politics is about distribution of resources, about the resolution of conflicts, indeed, it is about how power, that is, how authoritative decisions are taken and enforced.

\section{Hegemony}

The concept of hegemony centres on who is the master, a political force that decides the dominant forms of conduct, ideas, values and social practices in a given social context. Indeed, the construction and establishment of hegemony in society, is an exercise of almost importance, because hegemony is about a political force that determines the rules and the meanings in any social formation. And this is precisely because hegemony is a special type of articulatory practice that determines the dominant rules in any society. (Marsh and Stoker, 1995).

Hegemony is meaningful with the way the modern capitalist state functions, because the modern state is a vehicle through which one or more groups impose their values, ideas and the stratification system of the society upon other groups. (Hughes and Kroehler, 2002). Consequently, the modern capitalist state plays a dual role, first to guarantee the conditions of capitalist accumulation and reproduction and second to organise the legitimation of the capitalist socio-economic order. (Youngman, 2000). In doing so, the state uses political power which flows from intellectual, moral leadership, authority and consensus which are all different from armed force. (Arora, 2010).

Gramsci argues that hegemony displays an important emphasis on the role of consent within civil society as opposed to the use of pure force by the state. (cited in Marsh and Stoker, 1005). Gramsci elaborates the idea of hegemony which he says is the spontaneous consent given by the people to the general direction imposed on social life by the dominant group. (Arora, 2010). Again to Gramsci, the dominant group consists of leaders who wield state power by exercising leadership and domination. Thus, hegemony helps to attain and maintain dominance, more than force. In other words, hegemony refers to the way that class domination is based not simply upon coercion but upon the cultural, intellectual and ideological acquiescence of the subordinate classes. (Marsh and Stoker, 1995). This is why the consent of the dominated group does not come through fear or the force of the dominant group but through the efforts of the intellectuals who, acting as the agents of the dominant group, help to secure the consent of the dominated group. (Arora, 2010). This is because consent is a necessary component of the method of rule because even though force may be an effective means behind power, which is the ultimate foundation for the state, it is not the most effective means for political rule. (Hughes and Kroehler, 2002). 


\section{The State}

Although the concept of state is very current in the social sciences, it is worth noting that different theorists view the state in the background of their respective ideology and attitude which is why the concept of state is different from period to period and from age to age, from Plato to Marx. (Das, 2009).

Garner, (cited in Mahajan, 2014) says that the origin of the state is a matter of speculation and controversial discussion and that ever since thinkers began to philosophise, particularly on the concept of state, there has been a difference of opinion among them. In other word, nowhere in history where it has been clearly recorded when the state actually came into existence. Scholars, only imagine the various factors which might have contributed or were responsible for the origin of the state. Thus, how the state came into existence, in spite of its prominent role in the writings of social scientists today, is still an enigma. (Mahajan, 2014).

Although it is agreed that we do not know exactly the source and time of origin of the state, the movement of thoughts about the concept can be outlined as follows, from Divine, Evolutionary, Natural, Social Contract and Force Theories. The divine theory of state says that the state is a creation of God or some supernatural entity or power which established the state to maintain law and order and prevent a condition of anarchy. The natural theory explains that the sociable nature of man creates the union of males and females which developed into the family system, and then a tribe and a clan which eventually developed into a state. (Johari, 2012). The Evolutionary Theory believes that the state is the result of a very long and steady evolution in which factors of kinship, religion, consent and political consciousness played a part. The Social Contract Theory explains the idea that the authority of the ruler is based on some kind of agreement between him and his subjects. The theory is elaborated and expressed by the trinity of Hobbes, Locke and Rousseau between seventeenth and eighteenth centuries. The theory is a framework of a hypothetical state of nature, where the conditions of human existence were uncomfortable but because man wanted a near perfect environment to live, the state was created, which resulted from an agreement between the ruler and people.

The Force Theory on the other hand is neither about divine, evolutionary or natural origin of the state or is it about social contract and its fundamental principle of consent, the force theory is about the strong people subjugating the weak in society. This is where Marx makes his significant contribution to the concept of state. Thus, to Marxist theory, the state neither originates in the will of society nor it is maintained for the benefit of all sections of society, because the state does not come into existence for the fulfillment of a moral purpose, nor does it emanate from the will of the people because the origin of the state is as a result of conflict and the state then operates as an instrument of domination, the domination of the weak by the powerful. (Mahajan, 2014).

Consequently, for this paper, I will be adopting the force theory, using the Marxian perspective in the analysis of the state. And my choice of selection is based on the fact that the state as a major locus of power and authority in every modern society is relatively a new comer to political debate, because, until nineteenth century such concepts like political society, community, sovereignty, government, were common terms, used by thinkers. Even the concept of nation-state is a nineteenth century term, which stands for the whole society as well as its political apparatus. (Goodwin, 1987).

The modern state, a creation of capitalism, developed with the coming of industry and of complicated commercial arrangements and with large scale economic operations, the modern complex economic activities, the capitalists needed an institution to protect property. In 
addition, the capitalists needed to control workers because of the tension caused by exploitation, oppression and domination; therefore the state emerged, as an institution and also as an instrument of power for the capitalists. (Shively, 2012).

The state then emerged because it was made necessary by the modern capitalist economy and also because its emergence made it more possible for people to be easily controlled thereby making the state representing politics and power. (Shively, 2012). Today, the modern capitalist state remains a most significant force in shaping the economy of the society, thereby making it play an important role in the development of modern society. (Dicken, 2003).

Thus far, it can be argued that politics and power are together and cannot be separated. And also the search for power and the functioning of power are all politics. Therefore power, as a possession is very valuable in society. Indeed, power is closely linked to economics making power to be the instrument for the control of resources, particularly the control of production distribution and exchange. Consequently, power is the central part of politics while the state also needs power to be effective because the state cannot function, even perform the minimum function without power, because without power, policies cannot be formulated and implemented.

From the foregoing, people must struggle for power and to struggle for power, (politics) the state is needed to make rules and provide order while hegemony is needed to create a common culture and values that will make citizens accept and obey the state. In other words, two critical requirements for the struggle for power (politics) are the state (for order) and hegemony (the willingness to accept the values of the dominant class).

Thus, how are the state and hegemony in Africa, where citizens now periodically struggle for power?

\section{CAPITALISM, THE STATE AND HEGEMONY.}

Thus far, it can be argued that both the modern state and the idea of hegemony are rooted in the development of capitalism, that is, the modern state is a product of economic activities and hegemony is used by the dominant class in exercising the domination of the other social classes, with their consent, which has come into being with the rise of class contradictions. (Johari, 2012). And that is because, the capitalist economy rests on a fundamental dichotomy between capital and labour generating some contradictions that are transmitted at the level of social relations into the antagonistic relations between the haves and the have not. (Goodwin, 1997). Today, the modern state remains a unique political form, distinct from all past institutions in preceding political formations. (Hague and Harrop, 2010). Therefore, since its emergence, the state has become a powerful institution, being the power house of society; a social structure that now organizes, directs and executes policies for the entire society

From the above, we can make two deductions. One, that the modern state is a creation of capitalism, in that, the state did not emerge from social contract but it came into being as an institution for the dominant class that will protect its interest against the economically weak classes. Two, because of the conflict of interests that were engendered by capitalism and the subsequent class struggle, the property class, united by the ideology of private property, and in realization of the need to have a power that will mediate class struggle, so that they are not consumed in the ensued conflict, created an institution (the state) that will preserve its superior status and property. Thus, the state emerged, even though its emergence was not in the interest of the whole society but for the interests of the dominant economic class, in order to govern and control society (Mahajan, 2014). 
What comes out of the above is that, capitalism, as a mode of production must produce a capitalist class, that is, the property class, which becomes the dominant class in society and the dominant class must recognize the need to have a power that will protect their interests. However, once the state emerges to protect dominant class interests, its method of doing so will not be by force alone, the method must include persuasion, through hegemony, which, according to Gramsci, is embodied in intellectual, moral and political dimensions. While intellectual and moral hegemony are about leadership, the political dimension is about domination and subjugation, force and coercion. Thus, through hegemony, the education that is provided in society emanates from the intellectuals, and it is designed and applied to all, so as to obtain peoples consent and their collaboration. (Mahajan, 2014). In other words, the secured consent of the dominated classes in society is not as a result of the fear of the force or the punishment of the dominant class and their agents institutions but from the efforts of the intellectuals, who rationalize, on behalf of the dominant class, the ideas of the property class as the suitable and good ideas and values for all. Consequently, in modern society and with the capitalist mode of production, hegemony and the state are the hidden but powerful forces for the functioning of society in equilibrium.

Thus, if a society does not have a cohesive dominant class, but one that is in factions, the factions that are always in belligerent conditions, making it difficult for the class to define and agree on common interests, common values and common ideas so that with hegemony the interests, values and ideas are held by all, the struggle for power will certainly be chaotic in such a society. Also, if a society does not have a stable state, with the necessary class ideology of domination and a common class position, politics will necessarily be chaotic. In that case, how can we describe the conditions of hegemony and the state in post-colonial Africa, where the people now regularly struggle for power?

\section{HEGEMONY AND THE STATE IN AFRICA}

At the time European colonization began in Africa, the societies were dominated by slavery and feudalism as modes of production. At that time, the African societies were under the dehumanizing master-servant relation of slavery and the land tenant relation of feudalism. (Onimode, 1983). Thus, colonialism brought and instituted capitalism in Africa and as the capitalist mode developed extensively, it confronted the non-capitalist modes of production, slavery and feudalism and because the confrontation was aggressively conducted with superior technology/military power, capitalism triumphed. Colonialism, therefore, changed African social organization of production and replaced it with the capitalist system which involved private proprietorship, especially in peasant agriculture and in some few cases pettytrading. (Onimode, 1983). Colonial Africa was therefore linked with the outside world through the system of international capitalism. (Brett, 1977). So, with the triumph of capitalism, commodities in African societies became products for international market, making Africans to be engrossed in capitalist socio-economic production, thereby creating a colonial social formation, which led to a gradual break up of traditional landholding, (Onimode, 1983). Again, with colonialism, Africa was drawn into relations of dependence on metropolitan Europe, the development that restructured African societies to produce socio-economic relations that were both of pre-capitalist (slavery and feudalism) and capitalist systems.

Although the African societies were dominated by the international capitalist system, during colonial rule, the system did not lead to socio-economic development in Africa. And that was because the nature of the African societies was very different from the type that produced the original capitalist revolution in Europe. (Brett, 1977). Even though colonialism planted the capitalist culture in Africa, the result did not engender socio-economic development as it recorded for Europe. What it succeeded in doing for Africa was tying the continent to the apron 
spring of Europe, making Africa a net exporter of raw materials to Europe and a net importer of finished products, a relationship that is responsible for the under- development of Africa.

In Western Europe, capitalism evolved organically but was injected into African societies from outside, a system that eventually became an imposition precisely because, Africans were least prepared for capitalism at the time of its imposition. What is extremely important is that the organic evolution of capitalism in Europe produced an indigenous capitalist class which was rooted in the social structure, culture and values of the Europeans. In addition, the dynamics of the European societies at that time were in favor of the capitalist class, the class that, in turn, relied on those internal characteristics of the society for support and legitimation. (Brett, 1977).

Furthermore, the dominant character (values) of the capitalist class at the early stage of capitalist development was subjected to intense opposition both from the old feudal order and the emergent working class. What that development brought about was an institution, created by the blooming capitalist class to protect capital and allow it to grow and also to protect the capitalist class against the old feudal order and the exploited and oppressed working class. Thus, the institution was to mediate the antagonism between the capitalists, on one hand and the old order and the working class. In other words, a palpable class struggle needed to be mediated by an institution. That institution was the modern state, created by capitalism for the protection of the capitalist class. The modern state, therefore, evolved as a social force, which, though in favor of a dominating class, it could not be rejected by the citizenry, given the values, ideas, and the dominant culture in European society at that time. And that was because at that time, the dominant culture in Europe was rooted in liberalism, an ideology that actually reinforced capitalism. Consequently, the state was seen and accepted by Europeans as a needed institution, an institution that protects the liberal ideology of freedom, human right especially the right to own property and the institution that will create order so that the Hobbssian state of nature will be avoided.

From the foregoing, the following assertions can be made.

1 That pre-colonial African societies were at the stage of slavery and feudalism when they were colonized.

2 That there was no capitalist class in Africa before colonialism.

3 That there were no capitalist social classes in antagonistic relations before colonialism and capitalism were imposed on Africa.

4 That there was no state as a capitalist institution that represented the capitalist class to protect capitalist interests before colonialism.

In other words, the modern state was not in existence, in Africa, prior to the imposition of capitalism by colonial rule.

However, the colonial administration needed an institution to be able to run the colonial economy, because the administration needed the authority to tax the citizens, appropriate and transfer surplus production, and also to formulate policies regarding politics, society and the economy. Consequently, the European modern state was injected into Africa, as capitalism was injected and the colonial state was born, to protect the interests of the metropolitan capitalists in Europe. Thus, the colonial state became the managing agent of the dominant private interests of the capitalist system of Europe, with a vested interest in maintaining their dominance inside colonial African societies. It is against that background that a problem arose with the relationship between the colonial state and the social forces that were generated by 
the newly created system of colonial production. (Brett, 1977). That was the contradiction, together with some other forces, that led to the nationalist movements.

As noted earlier, colonial rule created some social forces that eventually became antagonistic with colonialism. These social forces were made up of African petty-bourgeoisie, the proletariat and the peasant social classes all that emerged in Africa with the appearance of private ownership of the means of production and property inequality (capitalism). The colonial state, out of necessity educated the African petty-bourgeoisie so that Africans can acquire European culture and European mode of thinking so that Africans are able to accept European values and ideology and be useful in colonial administration. Consequently, those Africans who had acquired European culture and education became confident with high expectations as a result of their newly acquired status that placed them in the position of local leaders. However, the expectations and hopes of the blooming African petty-bourgeoisie were regularly frustrated by the colonizers, because they (the colonizers) had exclusive claim to political power and were also in control of the economy. The African petty-bourgeoisie eventually became a formidable political force and began to challenge colonial domination. (Onimode, 1983). The dominant class then formed political parties and created socio/tribal movements as tools for waging the struggle for self determination. Consequently, the nationalist struggle made the petty-bourgeoisie to assume the position of local dominant social class, even though the dominance was only at the level of socio-political sphere.

The colonial economy was therefore affected by the dialectics of capitalism with profound effects on the colonial society from the point of view of the contradictions it generated, resulting in the agitation for change. Consequently, the local dominant class came together for the displacement of Europeans who exercised domination, especially at the economic and political spheres. Thus, colonialism created a situation which led to the contradictions that gave impetus to the rise of nationalist movement and liberation struggle in Africa; the development that enabled African educated elite class, to mobilize the masses against colonial rule.

However, it is pertinent to emphasise that the nationalist movement in Africa was more a struggle against colonial rule than what can be described as nationalism or a movement for nationalism. And that is because nationalism is a value, a political movement in which a people with a common culture, language and historical tradition, claim the right of self determination, (Gordon \& Gordon, 2007). But in Africa, the colonial territories that were ruled by Europeans were collections of different peoples (nations) who lack a common spirit, a common culture as one people so as to form a cohesive social body. (Nwabueze, 2010). What is important and which should be noted about the above description of colonized Africans, who struggled for self rule is that, apart from the extent of territory and the difference in language, between the different peoples, there are other fundamental differences, such as, in character, attitude, habits, way of life and social conditions, between them. In other words, some of the different peoples were even "antagonistic, mutually antipathetic, utterly incompatible and even bitterly hostile to each other." Nwabueze, 2010, pg. 48). Thus, the historical roots, cultural orientations and the social bases of the dominant classes in Africa were sharply different. (Diamond, 2015). Consequently, most of the political parties and the anti-colonial movements that were formed to fight for self determination were either ethnic based or were dominated by one ethnic group. As a result, the development crystallized into the creation of factions along ethnic lines, among the dominant classes. However, in spite of the existence of factions within the dominant classes, the struggle continued and that was because what was on the mind of African freedom fighters was just to secure political independence. In other words, the political struggle drew the people together only for opposition to their subjugation by an alien power. (Smith, 2009). 
Thus, the dominant classes in Africa were united only in their desire to throw off colonial domination because there was no other common binding identity than anti-colonialism. (Smith, 2009). This explains one unique but vital point about African people, with regard to post-colonial crises that ensued immediately after independence and that is that, each colonial territory in Africa "is indeed a conglomeration of a larger number of different nations, artificially pieced together with the weak glue of colonialism". (Nwabueze, 2010, pg. 48). Consequently, those who are dominant in terms of their positions in politics are not able to develop a trans-ethnic consciousness and coherence, (Diamond, 2015), because they are either tribal chieftains or are ethnic warlords who hold tight to ethnic identity and not national identity and that was because there truly was no national identity which all of them could claim.

In Africa therefore, there is no dominant class both in the Marxian sense of relationship to the means of production and in the Weberian sense of income or consumption power in relation to the market. (Diamond, 2015) In other words, there is no dominant class in terms of being socially dominant in the ownership or control of the most productive assets, or a dominant class that commands a sufficient monopoly over the means of coercion and over the cumulative socio-economic pre-eminence in society. (Diamond, 2015). Indeed, there is no national dominant class which is made up of individuals that own and control the apex positions in the economy, politics and society. Thus, the dominant class, as a result of their weak conditions, cannot evolve and install an enduring hegemony since independence, because they lack cohesion, discipline, intellectualism and foresighted leadership which now make it difficult to have a set of strong, stable and powerful state institutions. And which also makes it difficult for the African state to organize competitions for power (politics) or even manage crisis.

In spite of their weak conditions however, occasioned by intra-class struggle, the dominant class were motivated to pursue the struggle for self determination because of their desire to achieve elite social status so that they would inherit political power from the Europeans at independence, have access to the economy and accumulate wealth. Again, with the scarcity of private resources and opportunities, and the realization that political office could deliver the opportunities that will make them have access to the scarce resources, the struggle for political power was doggedly pursued. (Diamond, 2015). However, the development resulted in an inverted process of state formation and that is because unlike the Europeans who began with the nation and then evolved the state, colonialism first created the colonial state in Africa, which the Europeans used in ruling Africans but after independence Africans were now struggling to use the colonial state that was imported and imposed on Africa to build a nation. (Gordon \& Gordon, 2010). So, in Africa, colonial rule created a modern state that dwarfed all other organised elements of the economy and society. That is, a colonial state was created that extended and deepened its control over the society in terms of the economy and social life. In a nutshell, the colonial state controlled the means for personal income and modern occupational status as well as the control and distribution of national wealth. The colonial state, indeed, became the instrument for the formation and consolidation of class domination. (Diamond, 2015). And after independence, the inherited colonial state, even in their condition of flux, continued to play the roles that were played by the colonial state

With the intensification of the nationalist struggle, coupled with some political developments in other parts of the world, it was apparent that colonial rule would give way to political independence. However, what escaped the minds of the nationalists, at the time of the struggle, and which was extremely critical was whether the system of socio-economic and political organization that was established by the colonialists would be able to perpetuate itself, and be able to retain the capitalist system, produce indigenous groups that will be 
capable of replacing colonial rulers once political freedom (independence) is attained,( Brett,1977). It is important to realize that at the twilight of colonial rule, the African societies were just beginning to develop the features of the capitalist system. In a sense therefore, just before and immediately after independence there was no capitalist class to manage capitalism, no capitalist social classes for capitalist production and social relations, no capitalist institutions to form the basic superstructures of society, no local dominant class with the hegemony to construct hegemonic process for nationhood and no indigenous state to protect indigenous capital. Indeed, the African societies, at that time, had not evolved sufficiently strong and well rooted capitalist system at the time Africans were negotiating with Europeans over political power. Thus, at independence, African countries did not have a cohesive indigenous state nor were they with a dominant class with hegemony. And as it has earlier been argued, capitalism created the modern state and hegemony became the needed value to ensure capitalist class domination. However, because neither an indigenous African state nor indigenous African constructed and instituted hegemony was in existence in African societies at the time of independence, we can now begin to conjecture the kind of leaders that will succeed the European colonizers and their attitudes to the struggle for power and the type of societies that will emerge.

\section{CONCLUSION}

We have argued that in a capitalist system, there must be a dominant capitalist class, to create the state and possess hegemony so that while the state is the institution that represents dominant class interests, hegemony ensures that there is a general consensus on a common ideology and a common culture that are the ideas of the dominant class. Thus, in a capitalist system, the centrality of the economy in state formation process and in the construction of hegemonic order, by the dominant class, is without debate.

Since the independence of most of African countries, the level of the capitalist mode of production, with its attendant economy, capitalist values and capitalist culture are very low, resulting in very weak liberal capitalist ethos. This explains why, in Africa, the internal structure of capitalism is fragile and the African economy continues to depend on foreign support. Thus, the nature of the African economy is one that is characterised by low level of production, poor technology and lack of adequate manpower. Consequently, in today Africa, the people depend on the capitalist West and those developed countries in the East, to assist them in establishing the structures and institutions that are required for a strong capitalist formation.

As earlier noted, the private ownership of the means of production is sine qua non for capitalist dominant class to have domination and also to have hegemony, a cultural and ideological process that permeates society with bourgeois values and beliefs. (Marsh \& Stoller, 1995; Heywood, 2007). But colonialism instituted and imposed capitalism in Africa when Africans were at the stage of slavery and feudalism and at the time of independence, Africa had not evolved the institutions and the capitalist social classes to engage in and manage capitalist production. Consequently, in Africa, there is no ruling class, a class that is most powerful economically, for being in control of the economy and politics and also, there is no dominant class hegemony which embodies leadership, discipline, intellectualism and domination.

Soon after independence, therefore, most of the dominant classes in Africa were torn apart by their struggle for political power and because of that they were only too busy in their violent struggle to secure access and also to control the post-colonial state apparatus. Consequently, because of in-fighting, by factions of the dominant class, the dominant class could not develop the ability to speak with one voice as a strong and united class, so as to be able to evolve a virile 
state, and possess the needed hegemony for formalizing power. Consequently, because the dominant class was not united, it could not, as a class, provide the required hegemonic order for an emergent society. So, there has been, in most cases, throughout the continent, an apparent lack of nationally recognised and collective leadership. In Africa, it is apparent that leadership is devoid of cohesion, morality and the discipline required for the creation of strong state institutions, develop meaningful social structures for the society, because they possess very fragile legitimacy of authority.

In addition, the intra class struggle and the ensued violence create so much chaos which now inhibits the ability of the dominant class to institute hegemonic order, the order that should create the guiding values for the society. Unfortunately, in the apparent confused and state of flux that Africa has found herself, without a stable state, without a hegemonic class to provide accepted common values and socio-political culture for all, she still regularly organises elections for the belligerent factions of the dominant class to compete for power. No wonder there is so much chaos in the continent, where politics (competition for power), has become warfare, where there is apparent lack of morality on the part of the leaders, where there is so much corruption, where each year is worse than the previous year and where, according to (Hague and Harrop, 2010), there are 7 out of the 10 failed states in the world.

In summary, colonialism imposed capitalism when the people did not have the capacity to engage in capitalist mode of production the situation that continued till after flag independence. In other words, colonialism brought capitalism which inverted the process of creating a capitalist state, in that, the dominant class emerged at independence, not because they had control of the economy but because they championed the struggle for self determination. (Fadakinte, 2015)

Two, colonialism weakened African traditional economy, imposed European capitalist system which is made to depend on European capitalist system by tying it to international capital. Thus, because the economy is weak, it cannot produce capitalist social classes where there will be property class and properlyless classes with the former as the dominant class with common values, ideology and interests that will unite them and make them to possess hegemony and guide the society. In other worlds, the condition of the economy led to the in- cohesive dominant class and the absence of capitalist social classes. The situation also led to the absence of a ruling class, because no class is economically strong enough to be in control of the economy and politics.

Three, colonialism created political territories that are made of different peoples, of different cultures and history, of different values and philosophy, without any regard for national boundaries and ethnic/tribal identities and differences. This development later turned the different ethnic groups within the same countries, to different factions, after independence, leading to fierce struggle for power and making the competition for power a nightmare.

Four, the African society, after independence, did not have a strong and efficient state, precisely because the inherited colonial state could not function well after colonial rule and that is because, according to (Hague and Harrop, 2010) a state is not a prefabricated building, to be constructed on site from imported parts.

Finally, with the weak and dependent economy, the disorganized dominant class, the lack of capitalist social classes and the absence of a ruling class, politics inevitably is chaotic. Indeed, with the weak state and its agent institutions, the belligerent ethnic and tribal formations as factions, the struggle for power (politics) in Africa continues to be characterized by violence. 
This is because, in Africa, there is competition for power when there is no cohesive state as the institution to mediate the struggle for politics and where there is no hegemony to provide a common ideology, a common belief system and a common culture for all. In other words, there is no ideologically united dominant class whose ideas, values and culture will permeate the entire society, imbibed by the people and provide national cohesion.

\section{WHAT THEN IS THE SOLUTION?}

Africa needs to redefine those colonial legacies that now constitute her major problems; from the economy, education and state- society relations, but most particularly the artificial colonial boundaries. Today, most of the countries in Africa are bunches of incompatible tribes and ethnic formations. The ethnic formations are now the belligerent factions of the dominant class, those that fiercely engage in violent struggle for power. As a result, there is no cohesion among the dominant class and therefore it is difficult for a strong state to emerge or for a class to construct hegemony. Consequently, a redefinition of the colonial boundaries along ethnic lines will facilitate cohesion among the "same" people; generate a cohesive dominant class with hegemony which will ease the development of a healthy state that will utilize the constructed hegemonic order to develop the society. And one way to make this possible is to recognize the rights of ethnic groups for self determination in the constitution of each African country.

\section{References}

Agarwal, R.C. (2000). Political Theory: Principles of Political Science. New Delhi: Ram Nagar; S. Chand \& Co. Ltd. Anderson, J.E. (1997). Public Policy Making. New York: Houghton Mufflin Company. (3 $3^{\text {rd }}$ Edition),

Arora, N.D. (2010). Political Science for Civil Services Main Examination. New Delhi: McGraw Hill Education (India) Private Ltd.

Asirrathan, Edily and Misra, K.K. (2008). Politic Theory. New Delhi. S. Chand \& Co. Ltd.

Brett, E.A. (1973). Colonialism and Underdevelopment in East Africa: The Politics of Economic Change, 1919-1934. London: Nok Publishers.

Danziger, James N. (2001) Understanding the Political World. A Comparative Introduction to Political Sciences. New York: Addison, Wesley London.

Das, P .G (2009). Modern Political Theory. New Delhi. New Central Agency:

Dicken, Peter (2003) Global Shift Reshaping the Global, Economic Map in the 21 ${ }^{\text {st }}$ Century. New York: The Guilford Press.

Fadakinte, M.M. (2014). "Nigeria and Election Crisis: Debating the Causes". International Journal of Humanities and Social Sciences, Vol. 4, No. 6, pp. 74-85.

Fadakinte, M.M. (2017). "Hegemony and Crisis of State in Post-Colonial Societies". Journal of Sustainable Development in Africa, Vol. 9, No. 1, pp. 1-79.

Gauba, O. (2003). An Introduction to Political Theory, India, Macmillan Ltd, (4th Edition).

Giddens, Anthony; Held, David; Hubert, Don; Seymour, Debbie; and Thompson, John (1995). The Polity Reader in

Some Theory. Oxford, Polity Press.

Goodwin, Barbara, (1982). Using Political Ideas. Londonm: John Wiley and Sons.

Gordon, April and Gordon, Donald (2007). Understanding Contemporary Africa. London: Lynne Rienner Publishers. (4th edition)

Gramsci, Anthony, (1976). Prison Notebooks, New York: Oxford Univ. Press.

Hague, Rod and Martin Harrop (2010). Comparative Government and Politics. Palgrave London: Macmillan.

Heywood, Andrew (2017). Politics. New York: Palgrave Macmillan.

Hoffman, John and Graham Paul (2009). Introduction to Political Theory. London. Pearson Longman,

Hughes, Michael; Kroehler, Carolyn and Zanden, JamesW. Vander (2002). Sociology, the Core. New York: McGraw Hill. 
Hunt, Elgin F. and Colander, David C. (2008). Social Science; An Introduction to the Study of Society. New York: Pearson Longman.

Johari, J.C. (2012). Principles of Modern Political Science. Sterling Publishers Private Ltd., New Delhi.

Kesselman, Mar; Joseph, William A. (2013). Introduction to Comparative Politics. Wadswork, Boston, U.S.A:Krieger, Joel \& Cergage Learning.

Laski, Harold (2007). The Grammar of Politics. Delhi, India: Surjeet Pubs.

Lasswell Harold D. and Kaplan, Abraham (1976) Power and Society: A Framework for Political Inquiry; New Yale University Press

Lavenda, Robert H. and Emily, A. Schultz (2003). Core Concepts in Cultural Anthropology. New York: McGraw Hill.

MacIver, R.M. (1965). The Web of Government. New York: The Free Press.

Mahajan, V.D. (2008). Political Theory. New Delhi: S. Chand \& Co. Ltd.

Marsh, David and Stoker, Gerry (1995) Theory and Methods in Political Science. New York, St. Martins Press.

Martinussen, John (1997). Society, State and Market: A Guide to Competing Theories of Development. London: Zed Books Ltd.

Nwabueze, B. (2010). Colonialism in Africa: Ancient and Modern. Ibadan: Gold Press Ltd, Vol. 2.

Oke, Moles (2001). The Nature of Political Concepts and Ideologies. Ibadan: Hope Publications.

Onimode, Bade (1983). Imperialism and Underdevelopment in Nigeria. London: Macmillan Press Ltd.

Painter, Joe (1995). Politics, Geography and 'Political Geography', London, Arnold.

Ponton, Geoffrey and Gill, Peter (1996) Introduction to Politics. Oxford; Blackwell Publisher Ltd.

Painter, Joe (1995). Politics, Geography and 'Political Geography'. London: Arnold.

Sabine \& Thorson (1973). A History of Political Theory. New Delhi: Publishing Co. PVT, Ltd, $4^{\text {th }}$ Edition.

Sargent, Lyman Tower (2009). Contemporary Political Ideologies: A Comparative Analysis. Belmont USA:

Wadsworth cengage Learn.

Shively, W. Philips (2012). Power and Choice: An Introduction to Political Science. New York: McGraw Hill.

Smith, B.C. (2009). Understanding Third World Politics. London, Palgrave Macmillan.

Stokefield, Martin (2005). "From Colonialism to Post-Colonialism: Changing Modes of Domination in the Northern Asian of Pakistan". Journal of Asian Studies, Vol. 64, No. 4, pp. 939-973.

Storey, John (2001). Cultural Theory and Popular Culture. London: Pearson Prentice Hall.

Swingewood, Alan (1979). Marx and Modern Social Theory. London: The Macmillan Press.

Turner, John (2005). "Explaining the Nature of Power: A Three-Process Theory”. European Journal of Social Psychology, Vol. 35(1), pp. 1-22.

Youngman, Frank (2000). The Political Economy of Adult Education and Development. London: Zed Books. 